\title{
桂宮家の今出川屋敷における御茶屋について 一その沿革・特色・使い方と桂離宮など洛外の別荘との比較一 THE STUDY ON THE 'OCHA-YA' IN IMADEGAWA PALACE OF KATSURANO-MIYA HOUSEHOLD
}

\author{
小沢朝江* \\ Asae OZAWA
}

\begin{abstract}
Katsurano-miya household had three villas in Rakugai (a Kyoto suburb) except Katsura Villa, and had two palaces, called Imadegawa Palace and Ishiyakushi palace, in Rakucyu(kyoto city). This is the study on the Ocha-ya in the Imadegawa Palace. The results are as follows.

(1) There were six Ocha-ya in Imadegawa Palace when Prince Yakahito lived in that palace. They were called Sekio. Unsetsu, Kairaku. Undai, Sakuyu and Machibito. They all had existed in 1758.

(2) Sekio was build in 1727 at latest. This Ocha-ya was revered an anceptor, and was attached Futaba-tei tea celemony room which was the imitation of Shokin-tei tea celemony room in the Katsura Villa.

(3) Compared with the 0cha-ya in Imadegawa Palace and those in the villas in Rakugai, they had something in common. Build on a height with a fine view. commanded a enjoyable scenery of rice field, and setting the space of revering an anceptor insaide. and so on.
\end{abstract}

Keywords: Katsura Villa, Katsurano-miya household, Ocha-ya, Sukiya, palace 桂離宮、桂宮家、御茶屋、数寄屋、本邸

はじめに

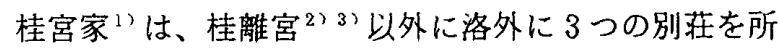
有し4)、また洛中に今出川屋敷と石薬師屋敷のふたつの

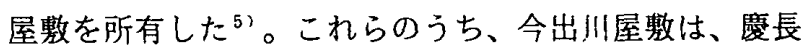
10年 (1605)の屋敷替以来の屋敷 ${ }^{6)}$ で、当初は本邸として 用いられた。しかし、元禄 9 年(1696)の石薬師屋敷拝領 後、宝暦11年 (1761)に8 代公仁親王が今出川屋敷に移る までの間、石薬師屋敷が本邸とされ、この間今出川屋敷 は「上御屋敷」「上御殿」等と呼ばれて四季折々の遊興 に利用された ${ }^{7}$ 。すなわち、今出川屋敷は本邸としての 役割のみでなく、別荘としての役割も持っていたのであ る。

『桂宮日記』81（以下『日記』と略記する）などの史 料によれば、今出川屋敷には複数の御茶屋 ${ }^{9}$ が建てられ ていた。これらの御茶屋の中には、後に詳しく述べるよ うに、桂離宮の御茶屋の写しを持つものなどがあり、洛 外の別茌と密接な関係を持っていた。この今出川屋敷の 御茶屋の様相を明らかにすることは、本邸に営まれた遊 興の施設の様相を明確にするのみならず、桂離宮など洛 外の別荘の性格や役割を明確にする上でも重要な意味を
持っている。

本研究は、桂宮家の今出川屋敷の御茶屋について、今 出川屋敷が別荘として使われた江戸時代中期を中心に、 桂離宮など洛外の別荘と比較しつつ、その沿革・特色・ 使い方等を明らかにするものである。

\section{1.今出川屋敷の御茶屋の浻革}

1-1 初代から 5 代親王までの今出川屋敷の御茶屋

今出川屋敷は、慶長10年(1605)の後陽成院御所造営に 先立って行われた屋敷替え以来の屋敷である ${ }^{6)}$ 。

知仁親王日記』10)によれば、慶長10年の屋敷替え 以前の桂宮家の屋敷には、慶長 7 年に「庭の御茶屋」が 建てられ、「茶屋二テ侍衆茶シノマスル」(同7·5・28)、

「庭ノ茶屋二テ乳人掓舞アリ」(同7・6・23）など茶の湯や 振舞に用いられている。

慶長10年の屋敷替え後、元和元年(1615) 6 月27日には 相国寺鹿苑院の院主听叔顕啅が今出川屋敷に招かれ、「園

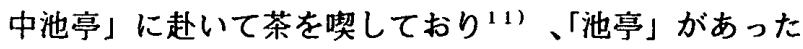
ことがわかる。庭の様子は「池水清而新竹茂、実奇観」 で、庭に「弥勒石像」があり、「亭」を「作」ってこの

* 湘北短期大学生活科学科 助手・工修

Reseach Assoc., Dept. of living Science, Shohoku Junior College, M. Eng. 


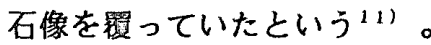

『隔筫記』寛永14年(1637)10月6日条によれば、今出 川屋數に去いて「於数寄屋、有御茶湯、御茶湯了、於御 茶屋、雲門、種々珍有、被勧杯」とあり、「数寄幄」で の茶の湯の後、「御茶屋」で酒肴等が出されている。

慶安 5 年(1652) 3 月28日、今出川屋敷に後水尾法皇が 御幸し、「八条殿之亭上」において「御遠見」をした ${ }^{12) 。 ~}$ この「亭」は、御殿を指すとも、庭などに作られた建物 を指すとも考えられる。

この今出川屋敖の建物は、万治 4 年(1661)に火災によ り焼失した ${ }^{13)}$ 。その後再建された屋數の様子は、莧文 13年(1673)に後西院仮御所となった際の指図 ${ }^{111 に よ っ ~}$ て窥うことができる。指図には、先の「弥勒石像」を納 めたと考えられる「弥勒堂」が敷地の東南に描かれてい るものの庭や御茶屋は描かれておらず、他に史㳆を久き、 この時期の様相は明らかではない。この指図の御殿は、 延宝 3 年 (1663) に焼失し、その後再建が行われている ${ }^{13}$

\section{1-2 6 代から 8 代親王までの今出川屆孉の御茶屋}

元禄 9 年 (1696) 7 月 6 日、6 代文仁親王は桂宮家を相 続し、同日石薬師屋敷を拝領すると、ここに御殿を造営 して同10年 6 月21日に移徙した7)。以後宝曆11年(1761) に 8 代公仁親王が今出川屋敷へ移徙するまでの70年間、 石薬師屋敷が本的となり、この間今出川屋敷は「上御屋 敷」「上御殿」等と呼ばれ、四季折々の遊與等に用いら れだ。

元禄15年10月 6 日、文二親王は今出川屋歌の「御庭南

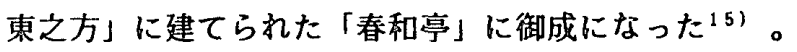

「春和亭」という名の御茶屋は、これより早く元禄13年 3 月23日に石薬師屋数に建てられていたことが確認され $3^{1{ }^{16)}}$ 。石薬溮屋政の春和亭は、文仁親王の実母である 敬法門院の「御有卦入」の祝いの宴のために建てられた

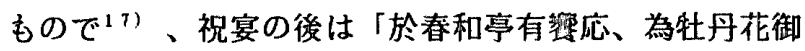

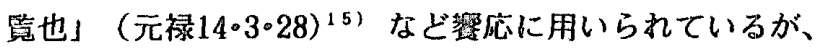
元禄14年 4 月 6 日に「今日春和亭二而准后様。宮様（中 略）御膳被召上谈」とあるのを最後に、『日記』には石 蔡師屋敷の春和亭に関する記事は見られないことから、 春和亭が石薬師屋敷から今出川屋敷へ移筑された可能性 が高い。

宝永元年(1704)10月18日には、今出川屋票の「東方御 山上」の「梯雲観」という御茶屋に御成があっだ日)。 この御茶屋は、「﨏腰挂」を「四面」に設けた作りで18)、 眺望を楽しむための御茶屋であったことが䚐われる。正 徳 5 年(1715) 10月 4 日の家仁親王の御成の際は、「御庭 御步行」の後、この梯雲観で管弦が行われている ${ }^{15)} 。$

『日記』宝厤 3 年10月19日条に収められている享保12 年（1727）12月26日付の『上屋敷附御道具并立具改帳』 （以下『立具改帳』と呼ぶ）によれば、今出川屋敷付の
道具や建具として、「御茶屋立具」が挙げられている。 『立具改帳』は、今出川屋敷の「御留守居」が交代する 際、今出川屋敷の什物を正確に引き継ぐため、屋敷内の 建具や畳のほか、屏風や茶碗の数量まで細かに書き上げ た文害で19)、この文書によれば豙保12年当時今出川屋 敷には「御茶屋畳」が12畳、「御仏堆、武間」の畳が 5 畳の規模を持つ「御茶屋」 1 棟が存在していたことにな る。20)この「御茶屋」は、仏間を持つ御茶屋であり、

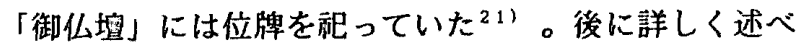
るように、宝暦頃には、やはり内部に仏間を持ち、位牌 を勈っている「赤黄」という御茶屋があり、年代子近い ことから、赤黄と『立具改帳』の「御茶屋」は同じ御茶 屋である可能性が高い。その場合、赤黄の造営年代は、 享保12年以前に遡ることになる。

『立具改帳』は、敦保12年のほか、宝暦 3 年 (1753) 9 月28日のものも存在する22)。宝曆 3 年の文書では、「御 茶屋」と「東御茶屋」の 2 つの御茶屋が挙げられ、この うち「御茶屋」は敦保12年の「御茶屋」と畳数や建具の 記述が一致し、同じ建物を示している。残る「東御茶屋」 は享保12年の文書にはまだなく、従って「東御茶屋」は 享保 12 年以後宝暦 3 年までの間に建てられたものと考え られる。

『今出河花之衔会』 ${ }^{23)}$ によれば、宝暦 3 年 3 月 16 日 に家仁親王・鳥丸光胤らが今出川屋敷を訪れ、雲雪とい へる亁にいたりてはなを見」たとあり、「雲鄷」という 名の御茶屋が存在している。先に見たように、宝曆 3 年 の『立具改帳』には「東御茶屋」と「御茶屋」の 2 棟の 御茶屋が挙げられており、このいずれかが雲雪に当たる ことになる。このうち「御茶屋」は、先に触れたように 「赤黄」と呼ばれる卸茶屋であると考えられ、残る「東 御茶屋」が雲雪である可能性が高い。

宝暦 4 年、家仁親王は 7 代公仁親王の結婚を機に家督 を䆶り、今出川屋敷に新たな御殿を建てて同年12月21日 移徙し、以後宝曆11年に再び今出川屋敷が本邸となるま での間、ここを隠居屋敷としだ》。『桂宮覚書留』2ه によれば、家仁親王がこの間に屋敷の「こっかしこにや とりをたて置」いたとあり、雲雪・偕楽・赤黄。待人・ 雲台。作遊の 6 つの御茶屋の名が挙げられている。この 6 つの御茶屋のうち、雲雪は先に述べた通り宝暦 3 年に は遅くとも存在し、また偕楽は『日記』宝暦 5 年 8 月 12 日条に「御庭於偕楽二、賜酒看」とあって遅くとも宝暦 5 年には存在しており、さらに赤黄は亭保12年の『立具 改帳』の「御茶屋」と同じ建物の可能性があることから 享保12年には存在していたと考えられる。また『日記』 によれば、宝暦 7 年 1 月に、いずれの御茶屋か不明だが 「御茶屋新造」が行われている25)。6つの御茶屋は、 『今出川御茶屋和歌』23)にすべてその名があり、その 詠人に鳥丸光能が含まれていることから、光胤が宝暦事 
件によって永蟄居に処せられる宝暦 8 年 7 月24日 ${ }^{26)}$ 以 前にはすべて完成していたことになる。

宝暦 9 年に公仁親王が再婚すると、同11年今出川屋敷 内に奥方御殿を新造し、家親王が石薬師屋敷へ移り、 公仁親王と妃が今出川屋敷に移って、今出川屋敨が本邸 となっだ)。『桂宮覚書留』によれば、この奥方御殿の 造営に際し、御殿造営に必要な敷地に建つ「やとり」を 解体し、偕楽・待人・作遊の 3 棟を鷹峰御屋敷へ、雲台 を御陵村御茶屋へそれぞれ移筑した。『桂宮覚書留』に は、赤黄について「此やとり八今に有」とあり、雲台な どの移筑後も赤黄は今出川屋敷に残されたとされ、また 『日記』に「今日当殿御花見也、赤黄御茶屋渡御」(日月和 6・3・10１5) とあって、赤黄の存在が確認できる。

\section{1-3 8 代親王没後の今出川屋敷の御茶屋}

8 代公仁親王が明和 7 年 (1770)に没した後、桂宮家は 跡継ぎがなく、公仁親王妃霊光院が「御家主」として当 主の代わりを勤めた ${ }^{27)}$ 。霊光院は、「御家主赤黄江御 成、御庭桜花御覧給」(明和 $9 \cdot 3 \cdot 8)^{15}$ ) など赤黄で花見を 楽しみ、また天明 2 年 5 月 16 日には「御家中一統在勤之 面々」20名に赤黄で酒有をふるまった。15)

天明 8 年(1788) 1 月 30 日、今出川屋敷と石薬師屋敷は 共に天明の大火によって焼失した ${ }^{15)}$ 。御殿は石薬師屋 敷に再建され7)、今出川屋敷には寛政 3 年(1791)12月 2 日「赤黄亭御仁間之分」が「出来」した ${ }^{15)}$ 。赤黄には、 後に詳しく述べるように宮家代々の位牌が納められてお り、御仏間之分」とはこの位牌を祀る部屋を指す。その 後の『日記』によれば、赤黄については「常照院殿正御 忌也、(中略）就同儀於今出川御屋敷赤黄亭御牌前江供朝 饌」(寛政3・12・4） ${ }^{15}$ )、「赤黄御牌前江供蓮飯」(同8.7・ 15） 15) など「御牌前」を使った記事が見られるのみで ある。赤黄のうち「御仁間之分」のみが建てられたこと を裏付けるものであろう。桂宮家は、寛政元年の霊光院 没後、文化 7 年 (1810)に第 9 代盛仁親王、天保 4 年(183 3)に第10代節仁親王がそれぞれ相続したが、いずれも 2 歳・4 歳で早世し27)、長く当主不在の状態が綍いたた め、遊興目的の御茶屋は建てられなかったのであろう。

弘化 4 年 (1848)、石薬沞屋敷の御殿を今出川屋敷へ移 築し、常御殿等を新たに建てて、今出川屋敷に本邸の機 能を移した”。この造営後の様相を描いた今出川屋敷の 指図 ${ }^{28)}$ には、赤黄の「御仙間之分」に該当する建物は 見られず、御茶屋と考えられる建物も描かれておらず、 このときまでに失われたものと思われる。

明治16年(1883)の桂宮家断絶 ${ }^{27)}$ 後、今出川屋敷は上 地され、御殿の一部は明治 $26 \sim 27$ 年に二条城本丸へ移筑 されだ”。

\section{2. 今出川屋敷の 6 つの御茶屋の立地・使い方}

以上のように、今出川屋敷には種々の御茶屋が存在し たが、特に雲雪・偕楽・赤黄・待人・雲台・作遊の 6 つ の御茶屋については、家仁親王がこれらの御茶屋を題材 に『今出川御茶屋景』23) 『於今出川二百首和歌 式部 卿宮御独吟』 23) などの和歌を詠み、また飛鳥井雅重を 「題者」として「雲雪花」「偕楽雪」「赤黄蒙」待人月」「雲 台望」「作遊蛍」「竹裹䉆」「社頭松」の「今出川八景」が選 定され ${ }^{29)}$ 、この八景を題材とした和歌等も残されてお り、これらの和歌や漢詩、『日記』の記事等によって6 うの御茶屋の様相を具体的に知ることができる。

以下、それぞれの御茶屋の立地・趣向・使い方等につ いて、和歌などの資料をもとに検討する。

(1)赤黄

赤黄は、『桂宮覚書留』に「前二やま吹・紅つつし有」 とあり、つつじの紅と山吹の黄に因んで付けられた名で ある。天明 3 年 3 月 26 日には霊光院が赤黄から「御庭幾 里志満花」を御覧になっており15) 、赤黄からつつじが 眺められたことが磪認できる。『今出川八景和歌』23) には「赤黄蒙」「おなし枝をそむるなかめもうすく こく寄やいろわく 庭のもみち葉」とあり、紅葉を楽 しむ御茶屋であった。『日記』によれぼ、「今当殿御 花見也、赤黄御茶屋渡御」(明和6 $\cdot 3 \cdot 10)^{15}$ )、「今日於赤黄 亭御茶屋、御家中一統（中略）睗酒看飯等」（天明2.5. 16）155など、宴や花見に利用され、また「桂光院宮御 影供也、赤黄御茶屋御床奉㫫尊影」(明和9・4・7 $)^{15}$ など、 初代智仁親王の忌日に赤黄の床に「尊影」を飾り「御影 供」30)をしている。

先に述べたように、今出川屋敷が天明の大火によって 焼失した後、寛政 3 年12月 2 日に「赤黄亭御仏間之分」 が「出来」( ${ }^{15)}$ 、同日桂離宮の園林堂から「代々之尊

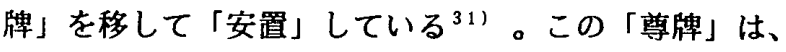

「火後園林堂被納」たため、今回「迎」えに行ったとあ り ${ }^{311}$ 、天明の大火後一時園林堂に納めたものであって、 火災以前は今出川屋敷にあったことを䙹わせる。『日記』 には「赤黄亭御霊前江御雑煮供之」(天明7・1・6) ${ }^{15}$ ) など とあり、天明の大火以前の赤黄亭にも「御霊前」、すな わち位牌を㖣る場所があったことが確認できる。先に示 したように、享保12年の『立具改帳』によれば、享保12 年当時今出川屋敷には「御仁壇、武間」を持つ「御茶屋」 が存在し、その「御仏壇道具」には「御位牌入箱」が含 まれており、また宝暦 3 年に「上御屋敷守護職」が交代 する際、その仕事として「御代々之御牌位御忌日朝供御 料、平日朝夕供燈明」が挙げられていて ${ }^{321}$ 、『立具改 帳』の「御茶屋」に仏間があり、その䎲壇に代々の位牌 を祀っていたことが判明する。仙間を持ち、位牌を祀る という「御茶屋」の特徽は、赤黄の様相とよく一致し、 この『立具改帳』の「御茶屋」が赤黄と同じ建物である 可能性が高い。 
赤黄は、『桂宮覚書留』に「赤黄、（中略）二葉と云 茶所有、是八かっらの松琴亭のかこいをうつせり」とあ り、桂離宮松琴亭の茶室の写しである二菒亭という「茶 所」があった。『桂宮御飾付』33)によれば、「二葉」 の名は桂離宮松琴亭と今出川屋敷赤黄の両方にあること に因んだもので、二茟亭の前の踏石や手水錬は土佐常覚 （光芳）の「作」であった。土佐常党は、宮家の御出入 絵師として絵の御用を勤めたほか、家仁親王の御伽衆の ひとりとして御成の御供等をしばしば勤め、また桂離宮 へも京保10年に 2 回、同11年に 1 回など計 6 回御供して いる ${ }^{341}$ 。また、「佐常覚体召参上、御茶湯御稽古有之」 （宝暦12・11・26）15）など公仁親王の茶の湯指南も勤め ており、このような立場から桂宮家の茶庭の造営に関与 したのであろう。『日記』によれば、宝曆 7 年 1 月6日 に「当殿御庭之内御茶屋新造」のため「方角吉方勧進」 が行われ ${ }^{15)}$ 、同月26日に土佐常覚が「御庭御用」のた め召されており ${ }^{51}$ 、このとき二集亭前の踏石等の整诺 が行われたと考えられ、また茶庭の整徣と茶室の造営が 同時に行われたとすれは、二葉亭の造営もこのときとな る。二葉亭は、「今日赤黄亭令成給、(中略) 先是二葉亭 数寄屋設茶湯」(天明 $4 \cdot 4 \cdot 1)^{15}$ 、、御入来青通院宮。知恩

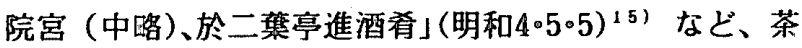
の湯や瑤応に用いられている。

(2)零雪

雲雪は、『今出川八景和歌』に「雲雪花」朝夕に 君 もなれミむ みよしの〉雲雪うつす 花のしろたへ」 とあり、桜を賞でる御茶屋であった。『今出河花之御会』 によれば、宝暦 3 年 3 月16日、家仁親王は鳥丸光胤らと 「今出川の別業の桜花さかり」を楽しむため今出川屋影 を訪れ、雲雪といへる幹にいたりてはなを見」ている。 今出川屋敨の桜は、『日記』に「一乗院宮以使被申上、 今出川御屋教花盛之躬也、（中略）今日御門前御往返之 序御立寄可有之由也、（中略）及夕陽一乗院宮御入来1

(享保19・3・10 ${ }^{151}$ とあるなど、他家からも見物に立ち 寄っており、『今出河花之御会』によればこの桜は「植 しより八十年にあまた木たかくなりつる」とあって、80 年余り前、すなわち延宝 3 年の火災後に植えられたもの であった。『桂宮覚書留』によれば、雲雪の額は花山院 常雅の筆であった。

先に述べたように、宝曆 3 年の『立具改帳』によれば、 この当時「御茶屋」と「東御茶屋」が存在しており、ま た雲雪も宝暦 3 年にはすでに建てられていることから、

『立具改帳』の 2 つの御茶屋のいずれかが雲雪であると 考えられる。このうち「御茶屋」は、先に指摘した通り 赤黄であると考えられ、残る「東御茶屋」が雲雪に当た る可能性が高い。「東御茶屋」の名は㖪地の東倒に位置 したための呼称と推測されるが、今出川屋敷の庭の東端

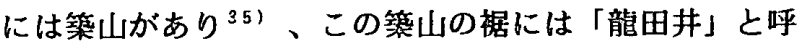

ぶ井戸があっで36)、『桂宮御飾付』に「たつたやト云 茶屋有、今たつた水云井の邉棝林二有、今は桂の賞花亭 是也」とあり、桂離宮の賞花亭が本来この井戸の傍にあ ったとされる。また「東御茶屋」は、『立具改帳』によ れば、畳は 5 畳で、御茶屋付の道具として「のれん、と んす一、木綿一」が挙げられており、のれんを賏ける趣 向に賞花亭との共通点が見られる。

(3)偕楽

偕楽は、『桂宮覚書留』によれば、その位置は「庭田 の前、春八菜花」とあり、また和歌に「偕楽より田面を ミて」37)「幾度か 風になるこもおとつれて あきの 田面を宿なから見る」 ${ }^{37)}$ とあって、庭内に作られた田 に面して建てられていた。『今出川八景和歌』には「偕 楽雪」なかかする 雪のあした八 おもひあへす 人も とひきてともに楽しむ」とあり、雪の景色を楽しむ御茶 屋であった。『日記』によれば、各御庭於偕楽睗酒看」

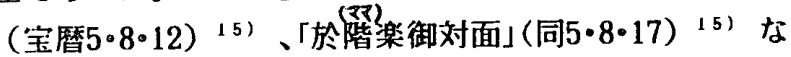
ど、玻応や対面に用いられている。『桂宮覚書留』によ れば、額の字は「広橋兼息卿筆」であった。 (4)雲台

雲台は、『今出河花月及紅葉の記』 ${ }^{23)}$ に「今出河の 別業にちいさき山をつくりて、いふせきやとりあり、こ の軒の名を雲台といふ」とあることから、庭内の筑山の 山上に位置し、また『今出川八景和歌』に「雲台望」た くひなき 雲の台の軒端より はるかにむかふ区方のや まやま」とあり、『今出川御庭八景詩歌』 ${ }^{23)}$ に「いつ よりか雲のうてなの軒端より むかう外山のかすむのと けさ」とあるなど、遠山等の眺望を楽しむ御茶屋であっ た。先に述べた通り、今出川屋敷には宝永元年当時敷地 の東方の築山の山上に、四周に腰脚けを設けた「梯雲観」 という御茶屋があり、眺望を楽しむ御茶屋が䆆り返し造 られている。『桂宮覚書留』によれば、雲台の額は「雲 の一字霊元院しんかんの写」であった。 (5)作遊

作遊は、『今出川八景和歌』に「作遊蛍」「つくりな すこ〉も沢辺と飛ほたる 軒か心影もいと〉涼しき」 とあるなど、蛍を楽しむ場所に建てられた御茶屋であっ た。また、5月 4 日夕のあやめ小きの行事の際は、「あ たらしき あやめの軒に折よくも す〉しくむかふ夕月 のかけ」37「「あやめふく 宿の軒はをてらしてや 巣 飛かふ〈れのす〉しさ」37) など、作遊の軒に菑蒲を 飾っている。『桂宮覚書留』によれば、作遊の額は「泪

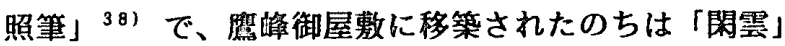
と呼ばれた ${ }^{39) 。 ~}$

(6)待人

待人は、『今出川八景和歌』に「待人月」「見人の 心もはれて 軒のはに まち出し月の 影のさやけさ」 とあり、『今出川御庭八景詩歌』に「皆人も月まこ 
よひ 軒端哉」とあるなど、月待ちをし、月を賞でる御 茶屋であった。また、「待人夜蛍」“0)など蛍を題材と した歌があることから、蛍の見える場所に建てられてい たと考えられる。『桂宮覚書留』によれは、額は「後西 院筆写」であった。

\section{3. 今出川屋敷の御茶屋と洛外の別茌との比較}

以上、今出川屋敷の御茶屋の様相について検討した。 今出川屋敷の御茶屋は現存せず、また指図等がないため 平面も明らかではない。しかし、今出川屋敷の御茶屋の うち、赤黄に桂離宮松琴亭の写しが造られ、また雲台や 偕楽が䳸峰御屋敷や御陵村御茶屋にそれぞれ移筑されて おり、洛外の別荘と合わせて考察することによって、今 出川屋敷の御茶屋の样相をより詳しく検討することがで きる。今出川屋敷と洛外の別茌は本来性格が異なるため、 比較にはおのずと限界があるが、両者を比較することに よってそれぞれの施設の持つ特徴を浮き雕りにすること ができると考えられる。

次に、今出川屋敷の御茶屋と、桂宮家が洛外に所有し た桂離宮・御陵村御茶屋・鷹峰御屋敷・長岡御茶屋の 4 つの別荘の御茶屋について、今出川屋敷が別荘として使 われた 6 代から 8 代親王の時代を中心に、御茶屋の楝数 ・立地・使い方・利用の実熊等について比較を行う。

\section{3-1 御茶屋の棟数と立地}

桂宮家の 4 つの別荘は、鷹峰御屋敷を除き11)、すべ て宮家の所領内に営まれた。敷地の広さは、『日記』明 治 3 年 4 月23日条によれば桂離宮が約 11,816 坪、鷹峰御 屋敷が約6264坪、長岡御茶屋が約4574坪（長岡天淦宮境 内を含む)、御陵村御茶屋が約512 坪（御茶屋山を除く） であった。また今出川屋敷は、明治 6 年の「邸地坪数街 届」42)によれば 4883 坪 5 分 4 厘であった。

敷地内に建てられた建物数を、6 代から8 代親王時代 の様相で比較すると、まず桂離宮は、現存する御殿群・ 園林堂・笑意軒・月波楼・賞花亭・松琴亭のほか、桂大 川に近い位置に竹林亭が存在し4 ${ }^{3)}$ 、御茶屋は 5 㤓であ った。鷹峰御屋敷は、主屋に相当する建物の存在は不明 だが、宝暦11年頃には月楼・閑雲・待人・偕楽・春秋の 5 棟の御茶屋があっだ4)。御陵村御茶屋は、書院と呼 ばれる40坪の建物と地蔵堂があり、背後の御茶屋山の山 上に雲台・邀月と呼ばれる御茶屋が設けられていだ5)。 長岡御茶屋は、御茶屋（古今伝授の間）、台所・料理場、 御客間があった ${ }^{46)}$ 。一方、今出川屋敷は、家仁親王が 隠居屋敷として用いた宝暦 4 年から宝暦11年の間が御茶 屋の数が最も多く、荤くとも宝暦 8 年には先に示した赤 黄・雲雪・喈楽・雲台・待人・作遊の 6 つの御茶屋が存 在した。

それぞれの御茶屋の立地を比較すると、いくつかの共
通点を見出すことができる。

まず、池や川などの水際に衔茶屋を設けている点であ る。桂離宮では、松琴亭や笑意軒が池に面して建てられ、 舟を着けて郝茶屋へ上がることができるようになってお り、また桂大川に近い東外山に竹林亭が建てられていた。 長岡御茶屋の場合は、敷地そのものが、天淦宮境内の八 条池に面していだ6)。鷹峰御屋敷には池はないが、敷 地西辺が紙屋川に接し44)『䳸峰記』23)によれは「そ れより竹林のうちなる坂をくたり、川辺ちかくにいたる、 此所は去年やすらひし所をもふけける」とあって、川辺 近くに御茶屋を設けていたことが䂓われる。今出川屋敷 では、作遊から蛍を眺め、门くりなすここも沢辺と 飛ほたる」 ${ }^{29)}$ などと詠んでいることから、作遊が水際 に建てられていたと考えられる。

次に、敷地内の高所に衔茶屋を設けている点である。 桂離宮では賞花亭を築山の山上に設けており、また長岡 御茶屋でも天淦宮南側の山上にかつて「上之御茶屋」が 設けられていたことが『長岡天淦宮覚書』 ${ }^{47}$ から判明 する ${ }^{46)}$ 。御陵村御茶屋では、敷地背後の御茶屋山の山 上に宝暦11年頃今出川屋敷から雲台を移築しており ${ }^{45)}$ また雲台の移筑以前にも山上に「邀月」という御茶屋が あったことが確認できる(5)。鷹峰御屋敷の場合、敷地 が上之壇と下之增に分かれ、両者の間に約 $20 \mathrm{~m}$ の高低差 がありいい、このうち上之增には月楼・閔雲・待人の少

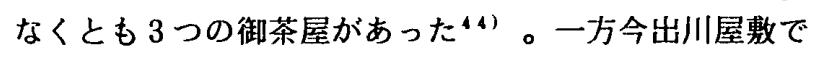
は、雲台が築山の上に位置し、この御茶屋から遠くの山 々の眺望を楽しんでおり、また宝永元年当時邸内の「東 方御山上」に「梯雲観」という御茶屋が存在した。

\section{3-2 御茶屋の趣向と使い方}

では、それぞれの御茶屋でどのような趣向を楽しみ、 どのような使い方をしたのか、共通点を挙げてみよう。

第一に、高所から景色を遠望している点である。先に 示したように、いずれの別荘にも敷地内の高所に御茶屋 が設けられ、御陵村御茶屋では「直到広野御山荘、御休

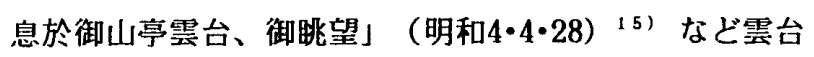
から跳望を楽しみ、鷹峰御屋敷では「月楼といふ茶屋に こしおろし、(中略) 軒ちかくむかふたかねあをあをとし けりたるあり、あれはいつくとたつぬるに、たか〉みね とこたふ、又つ〉きて山あり、琶がみ杍と申」“8) など 月楼から鷹峰・第峰を眺めている。また桂離宮の賞花亭 は、『桂別業図』、9 ${ }^{49}$ にれは、もとは現在地より東寄 りの築山頂上に位置し、向きも現在とは 180 度逆の南向 きであったことが指摘されており ${ }^{50)}$ 、本来は敷地の外 側を眺めることが意図されていたと考えられる。今出川 屋敷では、雲台から「四方のやまやま」29)を眺め、ま た 2 代親王時代の慶安 5 年にも「八条殿之亭上」で「御 遠見」をしており ${ }^{12)}$ 、眺望を楽しむための建物が絽り 
返し建てられている。高い場所から景色を望むための御 茶屋は、遊びの場に必須の要素であったとも言える。

第二に、田面の眺的を楽しむ点である。桂離宮の笑意 軒は、敷地の南端に位置し、「茶屋中二テ宜風景にて、 前八泉水、後八野辺 $习$ 見渡タリ、榴葉ノ躱面白シ」(延享 $3 \circ 9 \circ 3)^{511}$ 、「それより笑意亁といふ所にいたる、うし ろは野辺をみわたし、まへはつ〉じこ〉かしこに色こく

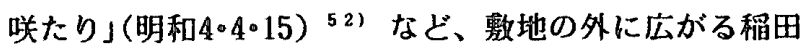
の様子を見ることが楽しみのひとつであった。御陵村御 茶屋は、かつては敷地の周囲一面が田であった ${ }^{45)}$ 。恣 峰御屋敷は「坂をのほりて䦥雲といへるやとりにいたり ぬ、そのふなからもひろき田面あり」 ${ }^{53}$ とあるなど庭 内に「田面」が作られ、䦥雲がその傍らにあった。また、 今出川屋敷においても、庭内に「田面」が作られ、田に 面して建てられた偕楽からその風景を楽しんだ。このよ うに、桂䧹宮などのように敷地周囲に田がある場合は、 その景色がよく見えるよう御茶屋を建て、今出川屋敷な ど周囲に田がない場合は庭内に田を作っており、田の風 景を見ることが楽しみのひとつであった。

第三に、御茶屋の中に宗教的な施設を併存する点であ る。桂離宮では、代々の位牌を祀る場として園林堂が設 けられていたが、先に述べた通り 8 代家仁親王時代は今 出川屋敷の赤黄の仏間にこれらの位牌が部られていたと 考えられ、天明の大火後も赤黄の仏間が再建されて、園

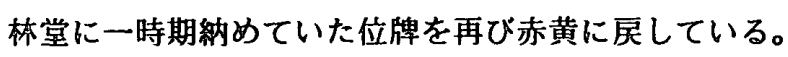

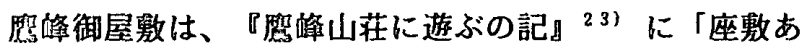
なたにこなたみはつるにひとつの位牌あり、立よつてみ るに敬法門院としるし侍る」とあり、いずれかの御茶屋 の中に、宮家 6 代文仁親王の実母である ${ }^{26)}$ 敬法門院の 位牌を祀っており、『磨酪覚』 ${ }^{23)}$ によれば敬法門院の 忌日である 8 月 30 日に留守居が花等を供えている。さら に、今出川屋晹の赫黄では、「桂光院宮御影供也、赤黄 御茶屋床奉憗尊影」(明和9・4・7 $)^{15)}$ など、初代親王の忌 日に床に親王の「尊影」を飾り、御茶屋の床を「御影供】 に用いている。また高松宮本『桂御別業記』541によれ ほ「園林堂、（中略）又細川幽斎玄旨画像陂納之、元長 風御茶屋古今御伝授之間二テ影供有之、当時此堂二被納 之」とあって、桂離宮園林堂に納的れていた細川幽汶 の画像 ${ }^{51}$ はかつて長岡御茶屋にあり、古今伝授の間で 「影供」をしたという。ただしいずれの場合も、砸って いる位牌や画像は、敬法門院が鹰酪御屋敦の元の持ち主 であり431、また細川龱斎が古今伝授の間で初代親王に 古今伝授を授けた人物である461 など、その建物に縁の 深い人物のものに限られている。また別荘全体を見ても、 御陵村御茶屋に地蔵堂が ${ }^{5}$ )、長岡御茶屋には長岡天满 宮があり ${ }^{46)}$ 、地菂堂や天满宮への参詣は御成の重要な 要素のひとつであって、遊びの場に宗教的な施設が無理 なく併存していたことも見過こすことができない。

\section{3-3 利用の実態}

次に、今出川屋敷と 4 つの別荏への御成の様子を検討 する。

今出川屋敷は、本蚛であった石薬師屋敷と同じ公家町 に位置した7”。例えば寛保 3 年の場合、『日記』によれ ぼ「午時前到有栖川宮、今出川屋敷給」(寛保3・9・23）15) など他の公家䄮への御成の際や、「直到川畸観音等給、 御帰路到今出川屋敷給」(同3・9・18）15）など社参の㴆途 に立ち寄る場合も含めて家仁親王の御成は11回に及び、 後に示す洛外の別荘への御成に比べ回数が多いが、本㿟 に近いという点以外に、洛外への御成には必要な武家伝 奏への届け出56) が洛中に位置する今出川屋敷の場合は

表 1 家仁親王 ·公仁親王の洛外の別庄への御成の回数

\begin{tabular}{|c|c|c|c|c|c|c|c|c|}
\hline \multirow{3}{*}{ 和 曆 } & \multirow{3}{*}{ 西相 } & \multicolumn{6}{|c|}{ 御成の回数 } & \multirow{3}{*}{ 備 考 } \\
\hline & & \multicolumn{3}{|c|}{ 家位親王 } & \multicolumn{3}{|c|}{ 公江親王 } & \\
\hline & & 挂・御陵 & 磪峰 & 長周 & 挂·御陵 & 篤峰 & 長岡 & \\
\hline 正徳 4 & 1714 & 1 & & & & & & \\
\hline 卓保完 & $\begin{array}{l}15 \\
16\end{array} \mid$ & & & & & & & \\
\hline & $\begin{array}{l}17 \\
18\end{array}$ & & & & & & & \\
\hline & $\begin{array}{l}18 \\
19\end{array}$ & & & & & & & \\
\hline & $\begin{array}{r}1720 \\
21\end{array} \mid$ & 1 & & 1 & & & & \\
\hline & 22 & & & & & & & \\
\hline 8 & $\begin{array}{l}23 \\
24\end{array}$ & 2 & & & & & & \\
\hline 10 & 25 & 2 & & & & & & \\
\hline $\begin{array}{l}11 \\
12\end{array}$ & $\begin{array}{l}26 \\
27\end{array}$ & 1 & & & & & & \\
\hline $\begin{array}{l}13 \\
14\end{array}$ & $\begin{array}{l}28 \\
29\end{array}$ & & & & & & & \\
\hline $\begin{array}{l}14 \\
15\end{array}$ & 1730 & & & & & & & \\
\hline $\begin{array}{l}16 \\
17\end{array}$ & $\begin{array}{l}31 \\
32\end{array}$ & 1 & & & & & & \\
\hline $\begin{array}{l}17 \\
18\end{array}$ & $\begin{array}{l}32 \\
33\end{array}$ & & & & & & & \\
\hline $\begin{array}{l}19 \\
20\end{array}$ & 34 & & & & & & & \\
\hline 元文范 & $\begin{array}{l}35 \\
36\end{array}$ & 1 & & & & & & \\
\hline $\begin{array}{l}2 \\
3\end{array}$ & 37 & 1 & & 1 & & & & \\
\hline & $\begin{array}{l}38 \\
39\end{array}$ & 1 & & & & & & \\
\hline 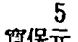 & 1740 & 1 & & & & & & \\
\hline $\begin{array}{r}\text { 睍保元 } \\
2\end{array}$ & $\begin{array}{l}41 \\
42\end{array}$ & 1 & & & 1 & & & \\
\hline 延安 $\frac{3}{\pi}$ & $\begin{array}{l}43 \\
44\end{array}$ & 1 & & & 1 & & & \\
\hline 2 & $\begin{array}{l}4 \pi \\
45\end{array}$ & $\frac{1}{2}$ & & & $\begin{array}{l}1 \\
2\end{array}$ & & & \\
\hline $\begin{array}{l}3 \\
4\end{array}$ & $\begin{array}{l}46 \\
47\end{array}$ & $\begin{array}{l}1 \\
1\end{array}$ & & & 2 & & & 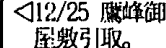 \\
\hline 睍延元 & 48 & & 1 & & 1 & & & \\
\hline $\begin{array}{l}2 \\
3\end{array}$ & $\begin{array}{r}49 \\
1750\end{array}$ & & 2 & & & & & “御台所向不 \\
\hline 宝曆元 & $5 !$ & & & & & & & 5 年間御成を \\
\hline $\begin{array}{l}2 \\
3\end{array}$ & $\begin{array}{l}52 \\
53\end{array}$ & & & & 2 & & & 挂える。 \\
\hline 4 & 54 & 1 & & & 1 & & & $\triangle 12 / 21$ 家估 \\
\hline & $\begin{array}{l}55 \\
56\end{array}$ & 1 & & & 1 & & & 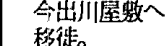 \\
\hline 7 & 57 & $i$ & 2 & & 2 & & $1^{*}$ & \\
\hline 8 & 58 & & 2 & & 1 & 1 & & \\
\hline 9 & $\begin{array}{r}59 \\
790\end{array}$ & 1 (1) & 3 & & $\frac{1}{2}$ & & & \\
\hline 11 & $\begin{array}{r}1100 \\
61\end{array}$ & 1(1) & $\begin{array}{l}6 \\
3\end{array}$ & & $\begin{array}{l}2 \\
2\end{array}$ & 1 & 1 & $<5 / 8$ 家作 石 \\
\hline 12 & 62 & & 5 & & & & & 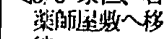 \\
\hline 明和䒕 & 63 & $1(1)$ & 4 & & 1 & & & 徘。 \\
\hline 明和元 & 64 & & 2 & & 1 & & & \\
\hline $\begin{array}{l}2 \\
3\end{array}$ & $\begin{array}{l}65 \\
66\end{array}$ & & $\begin{array}{l}2 \\
6\end{array}$ & & & 2 & & \\
\hline 4 & 67 & $1(1)$ & 2 & & I (1) & & $1^{\circ}$ & $\triangle A / 17$ 家侻范去 \\
\hline 6 & $\begin{array}{l}18 \\
69\end{array}$ & & & & $1(1)$ & & & \\
\hline 7 & 1770 & & & & $1(1)$ & & & $\checkmark 6 / 22$ 公口独去 \\
\hline
\end{tabular}

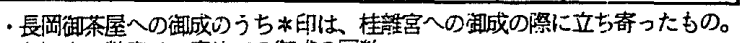
-( ) 内の数字は缩汽での御成の回数。

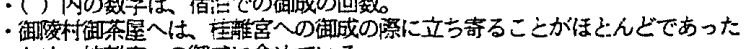
ため、挂離宫への湖成に含めている。

・根抱はいずれも伯記すによる。 
必要なかった点もその理由のひとつと考えられる。

表 1 は、家仁親王・公仁親王等の洛外の別荘への御成 の回数をまとめたものである。御陵村御茶屋へは、桂離 宮とともに訪れる場合がほとんどであった ${ }^{45)}$ ので、桂 離宮への御成に含めている。

家仁親王は、正徳 4 年(1714) 2 月29日、12才の時に初 めて桂離宮を訪れた ${ }^{15)}$ 。元文元年以降は、寛延元年か ら宝暦 2 年の 5 年間「御台所向御不勝手」のため御成を 控えた ${ }^{57)}$ のを例外とし、ほぼ毎年 1 ～ 2 回御成になっ ている。宝暦 9 年 6 月26日に初めて桂離宮に宿泊して ${ }^{58}$ 以来、桂への御成はすべて泊まりがけで行い、同年から 亡くなるまでの 9 年間に 4 回と回数が咸っている。一方、 鷹峰御屋敷への御成は、延享 3 年 (1746)に宮家の所有に なって以来、宝暦 6 年までの 10 年間にわずか 3 回であっ たが、宝糜 7 年頃から多くなり、宝暦 9 年には 3 回、同 10 年には 6 回と、桂への御成が泊まりがけで行われるよ うになるのとほぼ同時期に急增する。長岡御茶屋への御 成は、両親王を併せて 5 回である。

今出川屋敷・石薬師屋敷から洛外の別荘への距離は、 桂離宮へは御陵村御茶屋経由で的 $1 \mathrm{lkm}$ 、鹰峰御屋教へは 䄪 $5 \mathrm{~km}$ 、長岡御茶屋へは約 $17 \mathrm{~km}$ で、鷹峰御屋敷が最も近 い。家仁漞王が宝暦 9 年に武家伝奏に対し桂離宮への宿 泊を願い出た際、その理由として「家仁四十のころかつ ら領分別業ゆき向、往来朝夕なれば、労つよくて行かね ける (中略) 、家仁五十五の暮かつらの往来猶さら老ぬ るによりて (中略)、桂宿の事相談なと申侍る」58) と 述べているように、老年になり、遠い桂を訪れることが 体力的に難しくなり、代わりに近い鷹峰御屋敷への御成 が多くなったとみることができよう。

\section{4.今出川屋敷の御茶屋の特質}

以上、今出川屋敷の御茶屋と洛外の別荘の御茶屋との 比較を行った。今出川屋敷は、本邸から近いという利点 を持つ反面、洛中に位置するため、地形や風景は当然別 荘とは異なる。しかし、御茶屋の特徴や使い方を比較す ると、洛外の別荘の御茶屋も今出川屋敷の御茶屋も、そ れほど大きな相違が見られない。桂離宮や鷹峰御屋敷の ように敷地内に複数の御茶屋が存在する場合、ひとつは 水辺に、ひとつは高所に、ひとつは田に面する位置に配 置するなど、今出川屋敷と基本的な構成はほぼ同じであ る。これらの特徵は、御茶屋という建築に共通するもの とも言え、むしろ洛中にありながら洛外の別荘と同じ趣 向で楽しむ点が今出川屋數の特徴であるといえる。

今出川屋敷の赤黄など6つの御茶屋は、遅くとも宝暦 8 年頃にはすべて完成したと考えられ、この頃今出川屋 敷の御茶屋は最も充実した時期であった。また赤黄に桂 離宮松琴亭の茶室の写しが作られた時期は宝暦 7 年頃と 考えられるが、このように今出川屋敷の御茶屋が整備さ

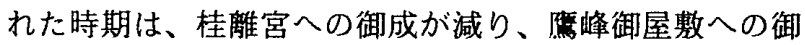
成が増えた時期とちょうど一致する。今出川屋敷の $6 \supset$ の御茶屋は、高齢になり体力が衰えて、遠い桂離宮をし ばしば訪れることができなくなった家仁親王が、桂離宮 に行かなくとも同じ趣向が楽しめるよう整備したものと 考えることができよう。

\section{おわりに}

以上、桂宮家の今出川屋敷の御茶屋について、沿革 . 立地・趣向・使い方等を明らかにし、桂宮家の洛外の別 荘の御茶屋との比較を行った。判明した諸点は次の通り である。

(1)家仁親王が㩊居屋敷として用いた宝暦 4 年から 11 年当 時、今出川屋敷には 6 つの御茶屋が存在し、名称は赤 黄・雲雪・偕楽・雲台・作遊・待人であった。このう ち、赤黄は遅くとも草保 12 年に、雲雪は遅くとも宝暦 3 年に、偕楽は遅くとも宝暦 5 年には存在したと考え られ、宝糜 8 年には 6 つの御茶屋すべてが揃ったと考 えられる。

(2)赤黄は、内部の仏間に代々の位牌を祀る御茶屋で、宝 暦 7 年頃には桂離宮松琴亭の囲を写したに二葉亭」を 増築した。二葉亭の作庭には、桂宮家の御出入桧師で ある土佐常覚 (光芳) が関与した。

(3)今出川屋敷の御茶屋と洛外の別荘の御茶屋を比較する と、水辺に衔茶屋を建てること、高所に御茶屋を作り 眺めを楽しむこと、田面の眺めを楽しむこと、御茶屋 内に宗教的な施設を併存すること、などの共通点が見 られる。

(4)家仁親王は、桂離宮をしばしば訪れたが、宝暦 9 年以 降御成の回数が減り、かつすべて泊まり挂けの御成と なり、逆に、鷹峰御屋敷への御成の回数は同時期に急 増する。また同時期に、今出川屋敷赤黄に松琴亭の囲 の写しが造られ、屋敷内の 6 つの御茶屋が完成してい る。今出川屋敷の 6 つの御茶屋は、体力的に桂離宮人 の御成が難しくなった家仁親王が、洛中にいながら桂 と同様の趣向が楽しめるよう整借したものと考えられ る。

[註]

1) 初代から 5 代まで八条宮、6代から8代まで京極宮、9代 から11代まで桂宮。ここでは特に必要な場合を除き、混乱 を避けて桂宮とする。

2) 桂離宮は、汀戸時代には「桂別業(『桂宮日記』延享 4 年 4月12日条）、「桂御殿（『桂宮日記』正德 4 年2月29日 条）などと呼ばれ、明治の桂宮家断絶以後桂離宮と呼ばれ た。本研究は江户時代を主に报うため、当時の呼称を用い ることが本来ふさわしいが、煩雑を避け、一般に知られて いる桂離宮の呼称を用いる。

3）桂離宮については多くの論考があり、ここでは本研究に特 に関連の深い著書を挙げておく。森䅛『桂離宮』東都文化 出版・昭和30年 久桓秀治『桂御所』新潮社 - 昭和37年 川上貢「桂離宮」（『原色日本の美術15 桂離宮と茶室』 
